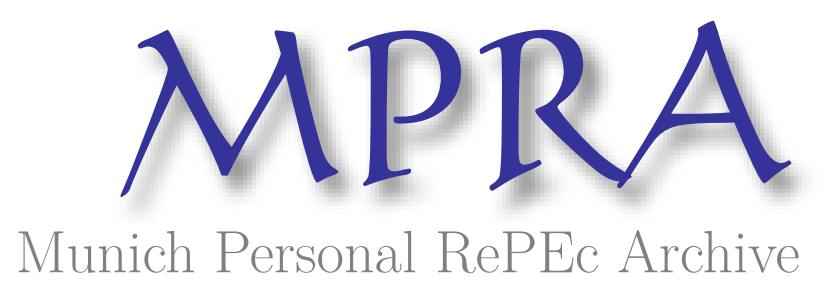

\title{
Going forward financially: credit unions as an alternative to commercial banks
}

Klinedinst, Mark

5 October 2011

Online at https://mpra.ub.uni-muenchen.de/33962/

MPRA Paper No. 33962, posted 08 Oct 2011 19:49 UTC 


\title{
Draft, October 2011:
}

\section{Going Forward Financially: Credit Unions as an Alternative to Commercial Banks}

\author{
Mark Klinedinst \\ Emeritus Professor of Economics \\ at the University of Southern Mississippi, Hattiesburg, MS \\ E-mail:mklinedinst@mac.com.
}

\begin{abstract}
The global financial meltdown brought to light a number of weaknesses in the U.S. financial system. Not all financial institution types will be taking large sums of taxpayer money to address their crippling decisions. Credit unions in the U.S. represent a type of financial cooperative that will probably not take any taxpayer money directly due to their structure and prudential oversight. Commercial banks, especially the megabanks, are likely to see even more bailouts in the future unless structural weaknesses are addressed in the clarifications as part of the enforcement of the Dodd-Frank Act. Using a unique panel data set on U.S. commercial banks, thrifts and credit unions from 1994 through 2010 (over 300,000 observations) performance metrics on a number of dimensions point to strengths and weaknesses of the various financial institutional forms. Credit unions also have had far fewer adjustable rate mortgages and mortgage backed securities as a percent of their portfolio. Robust estimators to correct for potential endogeneity are used to analyze the ROA differentials between different institutional forms and portfolios. When controlling for size, region and portfolios credit unions are estimated to have a better ROA. Institutions of under a billion dollars, 96 percent of the sample, show credit unions having higher efficiency in that they control 30 percent more assets per dollar spent on salaries than commercial banks. ${ }^{1}$
\end{abstract}

Journal of Economic Literature Classification Numbers: P0, P13, L21, G14, G21

Keywords: credit unions, banks, cooperative, defaults, net charge-offs, return on assets

1 Thanks to the participants of the International Economics Association, Tsinghua University, Beijing, China, July 2011 for insightful comments and suggestions. 


\section{Introduction}

The "Great Recession" has brought tremendous hardship to many across the globe. The finger pointing for who was at fault has not often strayed far from the financial sector and in particular the focus has often been on bank lending and regulatory oversight. What has often been missed in this focus has been the relative strength of the U.S.'s cooperative financial sector, the credit unions. Credit unions in the U.S. will ultimately probably not take a penny from the U.S. taxpayer in the form of a bailout for this crisis, while at the same time the amount given to commercial banks either directly or indirectly by a number of observers is well into trillions of dollars (e.g., Blinder and Zandi 2010 and the Congressional Oversight Panel 2010 and 2011). This paper will look at the U.S. financial sector and try to detect what early signals can be discerned that may help prevent a repeat of the current tragic contraction of world GDP and help develop prudential lending and regulatory practices by comparing the path various financial intermediaries have followed. Using a data set on all commercial banks, savings banks and credit unions in the United States for the last 17 years allows for comparisons between types of intermediaries that permits for controls for a number of different settings. This data set is quite unusual in its breadth and depth and makes possible an assessment of conditions precipitating the financial collapse across financial forms.

The regulatory environment is likely to change with the advent of the Dodd-Frank legislation in the U.S. and globally as well due to stiffer capital requirements in the Basel Accords (Stefan Walter, 2010). Although there is likely to be changes in the regulatory environment for all financial institutions, a number of the changes come 
about from a lack of appropriate oversight of proper lending safeguards, capital adequacy and firm governance.

The fallout from this financial crisis continues to be seen in the high number of institutional failures. From the start of 2008 until the end of 2010 there were 366 bank failures in the U.S. compared to 27 from the start of 2000 to the end of $2007 .^{2}$ Credit unions, although percentage wise their failures have been smaller they likewise have had trouble during the recession with 52 closures over the same three year period. This lack of failure during tough economic times and much smaller bailouts from the taxpayer make it no surprise that credit unions are the most common financial intermediary in the United States, and have been for some time. The institutional structure and practices differ quite a bit between credit unions, commercial banks and savings banks. Credit unions are financial cooperatives, one person-one vote rules prevail in determining management and are regulated by the National Credit Union Administration. Commercial banks and savings banks ${ }^{3}$ may be publicly traded joint stock companies and usually, especially commercial banks, have more diverse portfolios than credit unions and are regulated by the Federal Deposit Insurance Corporation or the Office of Thrift Supervision. To the average consumer sometimes the difference between these institutions is not apparent, but clearly the financial performance during this crisis and earlier crises often offer stark comparisons.

2 There were 45 failures in 2011 as of June 4th, 2011 for both commercial and savings banks combined (source FDIC). Eight credit unions have closed over this same period.

${ }^{3}$ Savings banks and savings associations are grouped together here. 
The next section will discuss the theory on different financial institutions and performance. The third section will examine the data used here and the empirical approach. The final two parts of the paper will focus on the empirical results and the policy implications that follow.

\section{Theory}

Credit unions and banks have a long history in the U.S. Although they generally fill a different niche in the market, they compete in some cases quite fiercely. Credit unions as financial cooperatives, based on the principle of one person-one vote, are non-profit institutions. Hence when comparing banks and credit unions a major question to be dealt with is what is the appropriate metric across such dissimilar institutions. Reporting to stockholders who want a good return on investments, managers would be keen to follow the return on assets (ROA). Credit unions, however, may be modeled as maximizing their shareholders income, quite a different maximand since for example the return retained by the credit union may make the income from deposits smaller for the shareholder (Bauer, 2010 and Sollenberger, 2008). Efficiency measures may sometimes work across institutions, but still typically suffer from the same confounding problems as the return on assets criterion. The ability to survive adverse conditions, contributions to the community (or minus in the case of bailouts), assets per employee or assets per dollar spent on salaries are all commonly used metrics.

Credit unions are typically much smaller than banks, hence their role as a small town lender is often similar to small banks. Like small banks in rural areas they play 
a key role in economic development by allowing small businesses the cash needed to get started or to continue to operate. This help to businesses is often indirect in the form of loans to an individual for home equity or personal loans (credit unions are proscribed by law to limit their business lending to 12.25 percent of assets ${ }^{4}$ ). In the U.S. then the credit union often plays the role of the Grameen bank by helping out small businesses. Certainly a useful metric then would be how many sucessful businesses started out with a loan from a credit union, savings bank or commercial bank, but alas this data is not readily available. Another metric that could be explored is the development of social capital (Aoki, 2010 and Klinedinst, 2007). How much trust does a customer feel towards their intermediary may be a useful metric if this could be measured. Does this trusting relationship depend on customer relations' strategies that may for example, at least temporarily, cause more employees to be added and then hurt the "bottom line?"

\section{Data and Methodology}

The data set covers all credit unions and banks in the United States from 1994 until December 2010, available from the FDIC and the National Credit Union Association (NCUA). Altogether there are 331,289 observations over the seventeen-year period.

\footnotetext{
${ }^{4}$ Credit unions are actively trying to increase this limit to 27.5 percent of assets arguing that this would create thousands of jobs and help diversify portfolios.
} 
Determining credit union and bank performance could be done, as mentioned already, by looking at returns on assets, net charge-offs, asset growth, number of failures, variants of the value-added approach or assets per employee. ${ }^{5}$

Generally the functional forms estimated can be posited as:

$\mathrm{Y}_{\mathrm{it}}=\alpha_{\mathrm{i}}+\beta \mathrm{X}_{\mathrm{it}}+\varepsilon_{\mathrm{it}}$

The performance indicator, $Y_{i t}$, used here is return on assets. The intercept, $\alpha_{i}$, captures firm specific factors which may be otherwise unseen, while the $\mathrm{X}$ matrix contains policy variables, state dummies, regional and time dummies to capture exogenous contemporaneous shocks. The use of firm specific intercepts helps to eliminate the bias that may be due, for example, to larger firms having the ability to use better technology or stronger market power. The time invariance of a credit union dummy variable that is used would in a fixed effects model mean these estimates would be unavailable. Using a random effects estimator allows us to keep this time invariant variable. The robust HuberWhite sandwich estimator allowed estimates of the standard errors in the presence of potential heterogeneity over such a diverse range of institutions. ${ }^{6}$ Possible endogeneity problems may arise, hence to correct for possible non-spherical errors terms the instrumental variable technique developed by Hausman and Taylor (1981) is used. This technique partitions the right hand side variables such that equation one can be rewritten as:

\footnotetext{
${ }^{5}$ See for example, Sollenberger (2008), Greer and Rhoades (1977), Lieberman and Asaba (1997), Berger and Humphrey (1992), Goddard J., McKillop D. and Wilson J. (2008), and Park and Weber (2006).

${ }^{6}$ White (1980).
} 
$Y_{i t}=\alpha_{i}+\beta X_{i t}+\gamma Z_{i t}+\varepsilon_{i t}$

Here $\mathrm{X}_{\mathrm{it}}$ is assumed to be exogenous and $\mathrm{Z}_{\mathrm{it}}$ contains elements that may be endogenous. Using a generalized instrumental variable estimator on this equation gives statistics that are asymptotically valid. This method allows estimation of the primary variable examined here, the time invariant dummies for whether the institution is a credit union, savings bank or a commercial bank. ${ }^{?}$

\section{Results}

Credit unions are the most numerous financial intermediary in the U.S. as can be seen in Table 1 where they make up just over 50 percent of the observations. Next in number are commercial banks with about 42 percent of the observations, with savings banks making up the remainder. The rate of return on assets is highest at commercial banks and lower at credit unions as theory would suggest and even lower at savings banks that have been hard hit by the decline in the housing industry. Total assets for intermediaries average $\$ 569$ million in 2010 dollars. Commercial and savings banks average about 15 times the assets of credit unions at 67.2 million. It is interesting to note that there are commercial banks that individually have more assets than all the credit unions combined (e.g., J. P. Morgan with $\$ 1.78$ trillion versus the combined assets of credit unions in 2010 of $\$ 934$ billion). The data on the number of employees is similar to that of real assets with the banks being eight to ten times as large as the average credit union.

\footnotetext{
${ }^{7}$ Woolridge 2006, p. 327, Baltagi and Khanti-Akom (1990) and Baltagi (2005).
} 
Assets per employee average about $\$ 4.7$ million dollars overall with commercial having the highest ratio at $\$ 7$ million dollars. Given that there may be large differences in the salaries the assets per dollar spent on salaries is also calculated. Here the ratios are much closer with an overall average of about $\$ 97$ and commercial banks again being the higher than credit unions and savings banks by approximately 8 percent. It is important to note that salaries sometimes make up a small percent of executive compensation at larger institutions since incentive payments in the form of bonuses, options, deferred compensation, etc. may approach 100 percent. Hence consideration of just salaries would mean that the assets to salary figures stated here would be substantially overstated for large institutions. To get around this problem and to make a comparison among similar sized institutions, the figures for "assets per dollar of salary" were also computed for all institutions with assets less than one billion dollars. This left approximately 96 percent of the sample and reversed the findings from the whole sample. Credit unions control about 30 percent more assets per dollar spent on salaries than commercial banks and about 12 percent more than savings institutions ${ }^{8}$. This appears to capture part of the impact that the approximately 100,000 volunteers contribute to the bottom line for credit unions and helps give them the financial power to give better rates. These results in favor of the credit unions may be just "the tip of the iceberg" if all incentive compensation was available. Loans to insiders, a potential loss to shareholders and members, averages about $\$ 2.4$ million dollars,

\footnotetext{
${ }^{8}$ Note the results reported in Table 1 for this variable dropped all values less than zero, even without this change the values were almost identical, e.g., 309,256 observations retained from 322,239.
} 
again commercial banks are the highest at $\$ 5.1$ million or 16.5 times greater than the credit unions.

The next series of variables relate to the asset portfolio. First mortgages average 11 percent overall with savings banks having the highest percent. Adjustable rate mortgages, which often were a problem in the housing collapse (Hampel et al, 2008) average 3.5 percent with credit unions having just 0.8 percent. Commercial and industrial loans average 4.5 percent with credit unions having just 0.3 percent and as expected commercial having twice the average. Credit card loans have a 1.4 percent average overall with credit unions having the highest percent at about 2.2 percent. Mortgage-backed securities average 3.5 percent of assets with credit unions having just 0.4 percent of the average. The last variable included in Table 1 is net charge-offs, uncollectable obligations minus that recovered. The average is about 32 basis points with credit unions having the highest average of 40 basis points.

The regression results presented in Table 2 from left to right increase in complexity in this unbalanced panel data set with 27,968 firms. Random effects models are in columns one and two, with column two including regional and state dummies as well, try to capture unobservable differences due to managerial ability, technology, etc. The Hausman-Taylor model used columns three and four take into account the potential presence of endogeneity, which the Durbin-Wu-Hausman test showed to be present. ${ }^{9}$ The additional controls in column 4 proved to be

\footnotetext{
${ }^{9} \chi^{2}$ of 7,200 with eleven degrees of freedom and a $p$ value of 0.00 .
} 
significant ${ }^{10}$, hence column four will be the main focus of the discussion on the econometric results. A dummy for institutions with assets over $\$ 50$ billion, "too big to fail," is included to try and capture any effects that come from such a large size and that may cause systemic risk.

The coefficient for the credit union dummy, relative to savings banks, is consistently positive and significant across all the specifications in Table 2 . The dummy representing commercial banks is positive and significant in all but the last column. The dummy for institutions that have assets of over $\$ 50$ billion is negative in all equations, but insignificant. Coefficients for assets and employees, an attempt to control for scale effects, are typically insignificant. Assets per employee and assets per dollar of salary also were not measured with much precision. Loans to insiders, a way to possibly measure hidden compensation, had a positive correlation with ROA, but again not significant in the endogenous equations in columns 3 and 4 . Portfolio variables on mortgages, credit card loans, commercial loans and mortgagebacked securities were all measured to be significant. Only credit card loans were estimated to have a negative impact. The coefficient on net charge-offs, as expected, is negative and significant in column four.

${ }^{10} \chi^{2}$ of 4,194 with twenty-nine degrees of freedom and a $p$ value of 0.00 . 


\section{Policy Implications}

Credit unions although the most numerous financial intermediary in the United States have an important role to play in that their failure rates are much less than other financial institutions. The small size of the institution may be an important factor in developing strong ties to customers that lead not only to trust and loyalty, but also to engendering pertinent information to offer loans and other services that are prudentially sound. Finding a good metric to measure performance across institution types is a difficult problem that offers no easy solution. For example, return on assets (ROA) is commonly used in many industries, but for associations and financial cooperatives this is not commonly seen to be the organizations primary objective. Efficiency measures are also problematic in many cases for spanning institutional forms since what may be efficient in one setting may be counter productive in another. Acknowledging the caveats about using the ROA nevertheless that is the main metric used here to compare the performance of credit unions, savings banks and commercial banks. As would be expected the average ROA at commercial banks is higher than found at credit unions and savings banks. The assets per dollar spent on reported salaries are similar for credit unions and savings banks, with commercial banks being a bit higher. This ranking is likely to be reversed when other forms of compensation are included (e.g., executive office space, jets, insider loans, etc.). This ranking is reversed also when large institutions with over a billion dollars of assets are excluded. When considering these smaller institutions, which include about 96 percent of the total observations, the credit 
unions average 30 percent more assets per dollar of salary than commercial banks. These figures which do not even include various expenditures on other forms of compensation show a considerable advantage that credit unions have in efficiency. This adjustable rate mortgages which were notorious in a number of instances of predatory lending were found to be a much smaller percent of assets at credit unions than either commercial or savings banks. Another area that probably has helped the credit unions fare better in this collapse is the much smaller percent of mortgage-backed securities, just 0.4 percent of the overall average.

The estimated equations show that when controls for size, region and portfolio distribution are taken into consideration that credit unions have a better ROA than commercial and savings banks, even though this is often not taken to be the primary goal of the credit unions. No discernable impact in the "too big to fail" category, here over $\$ 50$ billion in assets, was seen on ROA. A number of factors could be responsible for this strong performance with ROA and the lack of a large taxpayer bailout. This result could be from the network of trust that is often developed at credit unions in their goal to service their members, fewer cases of excessive executive compensation, the prudential avoidance of untenable adjustable loans, avoidance of mortgage-backed securities whose pricing was questionable and better regulatory oversight are all probably contributing influences. The small size of these financial cooperatives could give them an information advantage that allows for better decision making about a host of concerns, such as loan selection, choice of executives and their compensation, community awareness and developing connections to other credit unions. Although the results indicate a number of areas 
that appear to be have some of the answers to the diverse financial results of various institutional forms, the size of the data collected here is enormous and all the complicating factors of the macroeconomy leaves a good deal for future research. 
Table 1

Summary Statistics

\begin{tabular}{|c|c|c|c|c|c|}
\hline Variable $^{11}$ & Mean & St. Dev. & Min & Max & Number \\
\hline $\begin{array}{l}\text { Return on } \\
\text { Assets*** }\end{array}$ & 0.0075316 & 0.018461 & -0.9269855 & 0.9197733 & 331,289 \\
\hline Credit Unions & 0.0063958 & 0.016454 & -0.9269855 & 0.7486125 & 166,647 \\
\hline Savings Banks & 0.0058507 & 0.025132 & -0.7087379 & 0.8340615 & 25,884 \\
\hline $\begin{array}{l}\text { Commercial } \\
\text { Banks }\end{array}$ & 0.0092245 & 0.019140 & -0.8148771 & 0.9197733 & 138,527 \\
\hline $\begin{array}{l}\text { Total assets } * * * \\
(2010 \text { dollars })\end{array}$ & $569 \mathrm{m.} \$$ & 13 b. $\$$ & 0 & $1.78 \mathrm{t} . \$$ & 331,289 \\
\hline Credit Union & $67.2 \mathrm{~m} . \$$ & 386 m. \$ & 0 & 44.2 b. $\$$ & 166,647 \\
\hline Savings Banks & 1.03 b. $\$$ & 7.1 b. $\$$ & $123,293 \$$ & 370 b. $\$$ & 25,884 \\
\hline $\begin{array}{l}\text { Commercial } \\
\text { Banks }\end{array}$ & 1.08 b. $\$$ & 19.6 b. $\$$ & $67240 \$$ & 1.78 t. $\$$ & 138,527 \\
\hline Employees**** & 112 & 1944 & 0 & 231,333 & 331,289 \\
\hline Credit Union & 20 & 80 & 0 & 7,303 & 166,647 \\
\hline Savings Banks & 161 & 901 & 0 & 50,817 & 25,884 \\
\hline $\begin{array}{l}\text { Commercial } \\
\text { Banks }\end{array}$ & 213 & 2,976 & 0 & 231,333 & 138,527 \\
\hline $\begin{array}{l}\text { Assets per**** } \\
\text { Employee } \\
\text { (2010 dollars) }\end{array}$ & $4,745,623 \$$ & $149 \mathrm{~m} . \$$ & $0 \$$ & 37.2 b. $\$$ & 331,289 \\
\hline Credit Union & $2,562,328 \$$ & $2.1 \mathrm{~m} . \$$ & $0 \$$ & $254 \mathrm{~m} . \$$ & 166,647 \\
\hline Savings Banks & $5,663,224 \$$ & $13.6 \mathrm{~m} . \$$ & $61,647 \$$ & 940 m. \$ & 25,884 \\
\hline $\begin{array}{l}\text { Commercial } \\
\text { Banks }\end{array}$ & $7,092,385 \$$ & $228 \mathrm{~m} . \$$ & $19,553 \$$ & 37.2 b. $\$$ & 138,527 \\
\hline $\begin{array}{l}\text { Assets per Dollar } \\
\text { of Salary } \\
(2010 \text { dollars })\end{array}$ & $96.78 \$$ & $5,790.31 \$$ & $-45,536.13 \$$ & $2,847,655 \$$ & 322,239 \\
\hline Credit Union & $93.39 \$$ & $4,084.57 \$$ & $-45,536.13 \$$ & $1,515,178 \$$ & 158,164 \\
\hline Savings Banks & $93.78 \$$ & $343.93 \$$ & $0.14 \$$ & $41,119 \$$ & 25,871 \\
\hline
\end{tabular}

$11 * * *, * *$, and $*$ indicating significance at the 1,5 and 10 percent level, respectively for difference in means. 


\begin{tabular}{|c|c|c|c|c|c|}
\hline $\begin{array}{l}\text { Commercial } \\
\text { Banks }\end{array}$ & $101.22 \$$ & $7,684.97 \$$ & $-2,798.10 \$$ & $2,847,655 \$$ & 138,204 \\
\hline $\begin{array}{l}\text { Assets per Dollar } \\
\text { of Salary for } \\
\text { firms with Assets } \\
\text { under } 1 \text { billion } \\
\text { ( } 2010 \text { dollars) }\end{array}$ & $83.73 \$$ & $2923.08 \$$ & $0.14 \$$ & $1,515,178 \$$ & 309,256 \\
\hline Credit Union & $93.78 \$$ & $4103.40 \$$ & $0.66 \$$ & $1,515,178 \$$ & 156,587 \\
\hline Savings Banks & $83.19 \$$ & $168.01 \$$ & $0.14 \$$ & $22,563 \$$ & 22,849 \\
\hline $\begin{array}{l}\text { Commercial } \\
\text { Banks }\end{array}$ & $71.69 \$$ & $199.11 \$$ & $0.25 \$$ & $35,224 \$$ & 129,820 \\
\hline $\begin{array}{l}\text { Assets per Dollar } \\
\text { of Salary for } \\
\text { firms with under } \\
\text { a billion in assets } \\
\text { ( } 2010 \text { dollars) }\end{array}$ & $83.52 \$$ & $2,924.24 \$$ & $-45,536.13 \$$ & $1,515,178 \$$ & 309,263 \\
\hline Credit Union & $93.39 \$$ & $4,1045.00 \$$ & $-45,536.13 \$$ & $1,515,178 \$$ & 156,593 \\
\hline Savings Banks & $83.78 \$$ & $168.01 \$$ & $0.14 \$$ & $22,562 \$$ & 22,840 \\
\hline $\begin{array}{l}\text { Commercial } \\
\text { Banks }\end{array}$ & $71,67 \$$ & $199.27 \$$ & $-2,798.10 \$$ & $35,224 \$$ & 129,821 \\
\hline $\begin{array}{l}\text { Loans to } \\
\text { Insiders**** } \\
(2010 \text { dollars }) \\
\end{array}$ & $2,426,091 \$$ & $27.5 \mathrm{~m} . \$$ & $0 \$$ & 5.10 b. $\$$ & 331289 \\
\hline Credit Union & $310,062 \$$ & $1.5 \mathrm{~m} . \$$ & $0 \$$ & 0.30 b. $\$$ & 166647 \\
\hline Savings Banks & $1,690,478 \$$ & $16.9 \mathrm{~m} . \$$ & $0 \$$ & 2.07 b. $\$$ & 25884 \\
\hline $\begin{array}{l}\text { Commercial } \\
\text { Banks }\end{array}$ & $5,113,154 \$$ & $41.8 \mathrm{~m} . \$$ & $0 \$$ & 5.10 b. $\$$ & 138527 \\
\hline $\begin{array}{l}\text { First } \\
\text { mortgages } * * * \\
\text { percent of } \\
\text { assets }^{12}\end{array}$ & 0.1110537 & 0.1305835 & 0 & 0.991595 & 331,286 \\
\hline Credit Union & 0.0722717 & 0.1128349 & 0 & 0.9145243 & 166,644 \\
\hline Savings Banks & 0.2143539 & 0.2374389 & 0 & 0.991595 & 25,884 \\
\hline $\begin{array}{l}\text { Commercial } \\
\text { Banks }\end{array}$ & 0.1385907 & 0.1017258 & 0 & 0.9665815 & 138,527 \\
\hline $\begin{array}{l}\text { Adjustable } \\
\text { first } * * * \\
\text { mortgages } \\
\text { percent of assets }\end{array}$ & 0.0353121 & 0.0805795 & 0 & 0.9111944 & 331,286 \\
\hline Credit Union & 0.0084741 & 0.0395383 & 0 & 0.7730708 & 166,644 \\
\hline Savings Banks & 0.1567215 & 0.1641324 & 0 & 0.9111944 & 25,884 \\
\hline Commercial & 0.0449707 & 0.0699852 & 0 & 0.8563153 & 138,527 \\
\hline
\end{tabular}

${ }^{12}$ Note the figure for savings banks and commercial banks includes residences with up to four families. 


\begin{tabular}{|l|r|r|r|r|r|}
\hline Banks & & & & \\
\hline $\begin{array}{l}\text { Commercial and } \\
\text { industrial } \\
\text { loans*** } \\
\text { percent of assets }\end{array}$ & 0.0452425 & 0.0710911 & 0 & 1.0 & 331,286 \\
\hline Credit Union & 0.0034338 & 0.0276117 & 0 & 1.0 & 166,644 \\
\hline Savings Banks & 0.0250799 & 0.0400408 & 0 & 0.6306143 & 25,884 \\
\hline $\begin{array}{l}\text { Commercial } \\
\text { Banks }\end{array}$ & 0.0988948 & 0.0750369 & 0 & 0.9616175 & 138,527 \\
\hline $\begin{array}{l}\text { Credit card } \\
\text { loans** } \\
\text { percent of assets }\end{array}$ & 0.0139755 & 0.0458483 & 0 & 1.0 & 331,286 \\
\hline Credit Union & 0.0218609 & 0.0348321 & 0 & 0.9757313 & 166,644 \\
\hline Savings Banks & 0.0033647 & 0.0355006 & 0 & 1.0 & 25,884 \\
\hline $\begin{array}{l}\text { Commercial } \\
\text { Banks }\end{array}$ & 0.0064955 & 0.0563912 & 0 & 138,527 \\
\hline $\begin{array}{l}\text { Mortgage- } \\
\text { backed } \\
\text { securities*** } \\
\text { percent of assets }\end{array}$ & 0.0349667 & 0.0782623 & 0 & 0.9672325 & 331,286 \\
\hline Credit Union & 0.0001421 & 0.0037818 & 0 & & 138,527 \\
\hline Savings Banks & 0.1113306 & 0.1373305 & 0 & 0.9649894 & 25,884 \\
\hline $\begin{array}{l}\text { Commercial } \\
\text { Banks }\end{array}$ & 0.0626493 & 0.0882607 & 0.9672325 & 138 \\
\hline
\end{tabular}

\begin{tabular}{|l|r|r|r|r|r|}
\hline $\begin{array}{l}\text { Net charge- } \\
\text { offs*** } \\
\text { percent of assets }\end{array}$ & 0.0031981 & 0.0169807 & -1.076378 & 5.778124 & 331,286 \\
\hline Credit Union & 0.0040389 & 0.0103099 & -0.4261894 & 0.6933583 & 166,644 \\
\hline Savings Banks & 0.0014081 & 0.0136756 & -1.076378 & 1.683438 & 25,884 \\
\hline $\begin{array}{l}\text { Commercial } \\
\text { Banks }\end{array}$ & 0.0025265 & 0.0229094 & -0.0685947 & 5.778124 & 138,527 \\
\hline
\end{tabular}


Table 2

\section{Return on Assets, U.S. Data 1994-2010}

(Dependent variable is return on assets. Standard errors are in parentheses ${ }^{13}$ )

\begin{tabular}{|c|c|c|c|c|}
\hline & $\begin{array}{c}(1) \\
\text { Random Effects }\end{array}$ & $\begin{array}{c}(2) \\
\text { Random Effects }\end{array}$ & $\begin{array}{c}(3) \\
\text { Endogenous } \\
\text { Random Effects }\end{array}$ & $\begin{array}{c}(4) \\
\text { Endogenous } \\
\text { Random Effects }\end{array}$ \\
\hline $\begin{array}{l}\text { Credit Union } \\
\text { Dummy }\end{array}$ & $\begin{array}{l}0.0046081 * * * \\
(0.0007401)\end{array}$ & $\begin{array}{l}0.0046236 * * * \\
(0.0007317)\end{array}$ & $\begin{array}{l}0.0068408 * * * \\
(0.0006581)\end{array}$ & $\begin{array}{l}0.0057332 * * * \\
(0.0010151)\end{array}$ \\
\hline $\begin{array}{l}\text { Commercial Bank } \\
\text { Dummy }\end{array}$ & $\begin{array}{l}0.0017481 * * * \\
(0.0006662)\end{array}$ & $\begin{array}{l}0.0012737 * \\
(0.0006746)\end{array}$ & $\begin{array}{l}0.0022982 * * * \\
(0.0008642)\end{array}$ & $\begin{array}{l}0.0005906 \\
(0.0011515)\end{array}$ \\
\hline $\begin{array}{l}\text { "Too Big to Fail" } \\
\text { Dummy }^{14}\end{array}$ & $\begin{array}{l}-0.0006985 \\
(.0008782)\end{array}$ & $\begin{array}{l}-0.0003126 \\
(0.0009121)\end{array}$ & $\begin{array}{l}-0.0007 \\
(0.0009121)\end{array}$ & $\begin{array}{l}-0.0003488 \\
(0.0009642)\end{array}$ \\
\hline Ln(Assets) & $\begin{array}{l}-1.76 \mathrm{e}-14^{*} \\
(1.04 \mathrm{e}-14)\end{array}$ & $\begin{array}{l}-1.59 \mathrm{e}-14 \\
(1.24 \mathrm{e}-14)\end{array}$ & $\begin{array}{l}-1.49 \mathrm{e}-14 \\
(1.96 \mathrm{e}-14\end{array}$ & $\begin{array}{l}-1.30 \mathrm{e}-14 \\
(2.12 \mathrm{e}-14)\end{array}$ \\
\hline Ln(Employees) & $\begin{array}{l}1.76 \mathrm{e}-07 * * \\
(8.48 \mathrm{e}-08)\end{array}$ & $\begin{array}{l}1.37 \mathrm{e}-07 \\
(1.06 \mathrm{e}-07)\end{array}$ & $\begin{array}{l}1.52 \mathrm{e}-07 \\
(1.23 \mathrm{e}-07)\end{array}$ & $\begin{array}{l}1.01 \mathrm{e}-07 \\
(1.47 \mathrm{e}-07)\end{array}$ \\
\hline $\begin{array}{l}\text { Ln(Assets per } \\
\text { Employee) }\end{array}$ & $\begin{array}{l}-1.80 \mathrm{e}-19 \\
(3.16 \mathrm{e}-19)\end{array}$ & $\begin{array}{l}-1.66 \mathrm{e}-19 \\
(3.13 \mathrm{e}-19)\end{array}$ & $\begin{array}{l}2.13 \mathrm{e}-20 \\
(2.57 \mathrm{e}-19)\end{array}$ & $\begin{array}{l}6.86 \mathrm{e}-20 \\
(2.40 \mathrm{e}-19)\end{array}$ \\
\hline $\begin{array}{l}\text { Ln(Assets per } \\
\text { dollar on Salary) }\end{array}$ & $\begin{array}{l}-7.21 \mathrm{e}-21 \\
(6.57 \mathrm{e}-21)\end{array}$ & $\begin{array}{l}-5.73 e-21 \\
(6.93 e-21)\end{array}$ & $\begin{array}{l}-9.40 \mathrm{e}-21 \\
(7.16 \mathrm{e}-20)\end{array}$ & $\begin{array}{l}-7.66 \mathrm{e}-21 \\
(1.35 \mathrm{e}-19)\end{array}$ \\
\hline $\begin{array}{l}\text { Ln(Loans to } \\
\text { Insiders) }\end{array}$ & $\begin{array}{l}4.19 \mathrm{e}-12 * \\
(2.25 \mathrm{e}-12)\end{array}$ & $\begin{array}{l}4.61 \mathrm{e}-12 * * \\
(2.27 \mathrm{e}-12)\end{array}$ & $\begin{array}{l}4.28 \mathrm{e}-12 \\
(2.67 \mathrm{e}-12)\end{array}$ & $\begin{array}{l}4.56 \mathrm{e}-12 \\
(2.86 \mathrm{e}-12)\end{array}$ \\
\hline $\begin{array}{l}\text { Ln(First } \\
\text { Mortgages })\end{array}$ & $\begin{array}{l}0.0006985 * * * \\
(0.0000165)\end{array}$ & $\begin{array}{l}0.00013 * * * \\
(0.0000165)\end{array}$ & $\begin{array}{l}0.000161 * * * \\
(0.0000169)\end{array}$ & $\begin{array}{l}0.0001488 * * * \\
(0.0000195)\end{array}$ \\
\hline $\begin{array}{l}\text { Ln(Adjustable } \\
\text { First Mortgages) }\end{array}$ & $\begin{array}{l}0.0001724 * * * \\
(0.0000144)\end{array}$ & $\begin{array}{l}0.000178 * * * \\
(0.0000145)\end{array}$ & $\begin{array}{l}0.0002148 * * * \\
(0.0000141)\end{array}$ & $\begin{array}{l}0.0002158 * * * \\
(0.0000154)\end{array}$ \\
\hline $\begin{array}{l}\text { Ln(Commercial } \\
\text { Loans) }\end{array}$ & $\begin{array}{l}0.0000309 \\
(0.0000254)\end{array}$ & $\begin{array}{l}0.0000288 \\
(0.0000252)\end{array}$ & $\begin{array}{l}0.0001044 * * * \\
(0.0000239)\end{array}$ & $\begin{array}{l}0.0000995 * * * \\
(0.0000232)\end{array}$ \\
\hline $\begin{array}{l}\text { Ln(Credit card } \\
\text { Loans })\end{array}$ & $\begin{array}{l}-0.000143 * * * \\
(0.0000181)\end{array}$ & $\begin{array}{l}-0.0001408 * * * \\
(0.0000181)\end{array}$ & $\begin{array}{l}-0.0002092 * * * \\
(0.0000218)\end{array}$ & $\begin{array}{l}-0.0002166^{* * * *} \\
(0.0000213)\end{array}$ \\
\hline $\begin{array}{l}\text { Ln(Mortgage } \\
\text { Backed } \\
\text { Securities) }\end{array}$ & $\begin{array}{l}0.0002547 * * * \\
(0.0000232)\end{array}$ & $\begin{array}{l}0.0002549 * * * \\
(0.0000231)\end{array}$ & $\begin{array}{l}0.0002957 * * * \\
(0.000021)\end{array}$ & $\begin{array}{l}0.0002893 * * * \\
(0.0000257)\end{array}$ \\
\hline Net Charge-Offs & $\begin{array}{l}-0.1667685 \\
(0.0661885)\end{array}$ & $\begin{array}{l}-0.1668113 * * \\
(0.0661498)\end{array}$ & $\begin{array}{l}-0.1673002 * \\
(0.0955567)\end{array}$ & $\begin{array}{l}-0.1669671 * * \\
(0.0685504)\end{array}$ \\
\hline
\end{tabular}

$13 * * *, * *$, and $*$ indicating significance at the 1,5 and 10 percent level, respectively.

${ }^{14}$ Firms with over $\$ 50$ billion in assets. There were 494 observations in this group, 56 for savings banks and the rest were commercial banks. 


\begin{tabular}{|l|r|r|r|r|}
\hline Time Dummies & yes & yes & yes & yes \\
\hline Region Dummies & & yes & & yes \\
\hline State Dummies & & yes & & yes \\
\hline $\mathrm{N}$ & 331,283 & 331,283 & 331,283 & 331,283 \\
\hline $\begin{array}{l}\text { Number of } \\
\text { Groups }\end{array}$ & 27,968 & 27,968 & 27,968 & 27,968 \\
\hline Wald $\chi^{2}$ & 8,199 & 14,067 & 21,206 & 3,461 \\
\hline
\end{tabular}




\section{References}

Aoki, Masahiko, 2010, " "Individual" Social Capital, "Social" Networks, and Their Linkages to Economic Game," Annual World Bank Conference on Development Economics.

Baltagi, B. H., 2005. Econometric Analysis of Panel Data, Wiley, New York

Baltagi, B. H. and S. Khanti-Akom, 1990. "On the Efficient Estimation with Panel Data: An Empirical Comparison of Instrumental Variable Estimators, Journal of Applied Econometrics, 5, 401-406.

Berger, A.N. and Humphrey, D.B. (1992). Megamergers in banking and the use of cost efficiency as an antitrust defense. The Antitrust Bulletin, Fall: 541-600.

Bauer, Keldon, 2010, "What does credit union ROA really measure?, http://southwesternfinance.org/conf-2010/C5-1.pdf.

Blinder, Alan S. and Mark Zandi, 2010, "How the Great Recession Was Brought to an End," Moody's, http://www.economy.com/mark-zandi/documents/End-of-GreatRecession.pdf.

Congressional Oversight Panel, "The AIG Rescue, Its Impact on Markets, and the Government's Exit Strategy," http://cop.senate.gov/documents/cop-061010report.pdf Accessed June 30, 2010.

Congressional Oversight Panel, "The Final Report of the Congressional Oversight Panel," http://cybercemetery.unt.edu/archive/cop/20110401232213/http://cop.senate.gov/ documents/cop-031611-report.pdf, March 16, 2011.

Goddard J., McKillop D. and Wilson J. " Consolidation in the US Credit Union Sector: Determinants of Failure and Acquisition", FDIC, www.fdic.gov/bank/analytical/cfr/Goddard_McKillop_Wilson.pdf, 2008.

Greer, Douglas F. and Stephen A. Rhoades, 1977. "Test of the Reserve Labour Hypothesis” The Economic Journal, Vol. 87, No. 346 (Jun., 1977), pp. 290-299

Hampel, Bill, Mike Schenk, and Steve Rick, 2008. "The U.S. Mortgage Crisis Causes, Effects and Outlook Including Suggested Credit Union Responses" Madison, Wisconsin: Credit Union National Association. 
Klinedinst, Mark, 2007. "Cooperative Comebacks: Resilience in the Face of the Hurricane Katrina Catastrophe," Filene Research Monographs.

Lieberman, Marvin B. and Shigeru Asaba, 1997. "Inventory Reduction and Productivity Growth: A Comparison of Japanese and US Automotive Sectors,"Managerial and Decision Economics, Vol. 18, pp. 73-85.

Park, Kang H. and William L. Weber, 2006. "Profitability of Korean banks: Test of market structure versus efficient structure," Journal of Economics and Business, Vol. 58, pp. 222-239.

Sollenberger, Harold M., 2008, Financially "High-Performing" Credit Unions: Evaluating Performance within a Strategic Financial Vision," Filene Research Monographs.

Walter, Stefan, Secretary General, "Basel III and Financial Stability," Basel Committee on Banking Supervision, at the 5th Biennial Conference on Risk Management and Supervision, Financial Stability Institute, Bank for International Settlements, Basel, 3-4 November 2010.

White, H. 1980. "A Heteroskedasticity-Consistent Covariance Matrix Estimator and a Direct Test for Heteroskedasticity," Econometrica 48, 817-838.

Woolridge, Jeffrey M. 2006. Econometric Analysis of Cross Section and Panel Data, MIT Press, Cambridge Massachusetts. 
